\title{
Effects of protozoan herbivory and carnivory in a microplankton food web
}

\author{
Diane K. Stoecker ${ }^{1} \&$ Geoffrey T. Evans ${ }^{2}$
}

${ }^{1}$ Biology Department, Woods Hole Oceanographic Institution, Woods Hole, Massachusetts 02543, USA

${ }^{2}$ Northwest Atlantic Fisheries Centre, P. O. Box 5667, St. John's, Newfoundland, Canada A1C 5X1

\begin{abstract}
The estuarine ciliates Favella sp. and Balanion sp. both feed on the dinoflagellate Heterocapsa triquetra, and Favella also feeds on Balanion. In laboratory experiments, transient dinoflagellate populations were higher than would be expected if the effects of the 2 grazers were additive; in some experiments the presence of Favella was associated with higher $H$. triquetra populations. In a theoretical model, increasing the rate of predation on a species could increase that species' steady-state concentration. The relative gross growth efficiencies in this model have an important influence on ecosystem structure. These effects may be important in regulating population densities in microplankton communities in which omnivory is common.
\end{abstract}

\section{INTRODUCTION}

Microzooplankton, including ciliates, are important consumers of phytoplankton in many marine planktonic communities (Heinbokel 1978, Heinbokel \& Beers 1979, Capriulo 1982, Landry \& Hassett 1982, Capriulo \& Carpenter 1983, Verity 1984). In general, the larger planktonic ciliates (mostly tintinnids and oligotrichs) have been assumed to eat algae, but some may eat smaller ciliates as well (Blackbourn 1974, Robertson 1983). Carnivory among the microzooplankton would affect estimates of the feeding impact of microplankton as individuals (but perhaps not as a communityl from incubation experiments using natural assemblages (Capriulo \& Carpenter 1980, Landry \& Hassett 1982). More interestingly, omnivory could partially control the trophic dynamics and structure of microplankton communities. Omnivorous habit may contribute to the resiliency of planktonic communities (Landry 1981) and decrease the potential secondary production by creating horizontal links (Steele 1974). Isaacs $(1972,1977)$ has suggested that most marine food webs are unstructured (omnivory is common), but within a highly structured part of a food web the consequences of being both a competitor of and a predator on another species would be different. We refer to such a situation as a trophic triangle.

We have investigated such a trophic triangle. Dino- flagellates often dominate the phytoplankton standing crop in salt ponds (small estuaries) on Cape Cod, Massachusetts. Heterocapsa triquetra (Ehr.) Stein is one of the most common dinoflagellates, often occurring in almost monospecific blooms. It is about $16 \times 22$ $\mu \mathrm{m}$ in size. The naked ciliate, Balanion (sp. nov., Coats \& Small unpubl.) is sometimes associated with $H$. triquetra blooms in these estuaries (Stoecker et al. 1983). Balanion is about $32 \times 34 \mu \mathrm{m}$ in size. Favella sp., a large tintinnid (oral diameter 65 to $75 \mu \mathrm{m}$ ), is usually associated with spring and fall dinoflagellate blooms in these estuaries (Stoecker et al. 1984). In the laboratory, both Favella (Stoecker et al. 1981) and Balanion (Stoecker unpubl.) are selective predators on dinoflagellates. Favella is large enough to feed on Balanion. We determined the growth rates and gross production efficiencies of both ciliates, investigated predation by Favella on Balanion, and studied the effects of the interaction between Favella and Balanion on $H$. triquetra populations in multispecies cultures.

We then investigated a simple triangular model of this 3 -species interaction. The properties of 3-species systems in which there is 1 predator and 2 prey (reviewed in Levandowsky 1977), 3 competitors (Rescigno 1968), or a linear food chain (Rescigno \& Jones 1972) have been investigated. Although triangular interactions may be quite common in the plankton, this type of interaction had not been previously investigated. 


\section{EXPERIMENTAL METHODS AND MATERIALS}

Culture of dinoflagellate and ciliates. Experiments were run with cultured Heterocapsa triquetra algae (Strain A984), Balanion sp., and Favella sp. All 3 were isolated from Perch Pond. The algae were grown in enriched seawater medium f/2 (Guillard 1975), except that silicic acid was omitted, on a $14: 10 \mathrm{~h}$ light: dark cycle under $291 \mu \mathrm{Em}^{-2} \mathrm{~s}^{-1}$ of cool-white (Sylvania Co.) fluorescent light at $20^{\circ} \mathrm{C}$. Favella was cultured in aged, diluted Sargasso seawater (salinity about $31 \%$ ) to which $0.01 \mathrm{ml} \mathrm{l}^{-1}$ of $\mathrm{f} / 2$ iron-EDTA trace-metal solution (Guillard 1975) was added. This medium was autoclaved in teflon bottles, cooled, and then poured into sterile polycarbonate flasks. Favella were fed approximately $10^{3}$ cells $\mathrm{ml}^{-1}$ of $H$. triquetra and grown at 15 or $20^{\circ} \mathrm{C}$. Culture methods for Balanion were similar to those for Favella except that Balanion was fed approximately $10^{4}$ cells $\mathrm{ml}^{-1}$ of $H$. triquetra and maintained at $15^{\circ} \mathrm{C}$.

Experiment 1: growth curves. The first experiment was designed to document the growth of Favella sp. and Balanion sp., alone and in each other's presence, over a period of days. Duplicate 21 flasks containing 11 of medium were used for each treatment. The 4 treatments were: (1) Heterocapsa triquetra alone; (2) $H$. triquetra plus Balanion; (3) $H$. triquetra plus Favella; (4) H. triquetra plus Balanion and Favella. Flasks were inoculated at the following densities on Day 0: $H$. triquetra, 1000 cells $\mathrm{ml}^{-1}$; Balanion, 0.5 cells $\mathrm{ml}^{-1}$; Favella, 0.5 cells $\mathrm{ml}^{-1}$. These densities are within the ranges we have observed in the estuary (Stoecker et al. 1984). Flasks were incubated in the light at $15^{\circ} \mathrm{C}$. On the day after inoculation (Day 1) each flask was gently mixed and a $60 \mathrm{ml}$ sample was withdrawn with a serological pipette. The sample was fixed with acid Lugol's solution. Sampling was repeated daily until the populations declined. Subsamples were taken from the fixed samples, settled, and counted using the inverted-microscope method. The ciliates in $25 \mathrm{ml}$ were counted, unless densities were greater than 15 $\mathrm{ml}^{-1}$, when the ciliates in $10 \mathrm{ml}$ were counted. Logarithms of mean densities were plotted against time to determine the periods of exponential growth. Growth rates and generation times in $\mathrm{h}$ were calculated for these periods using standard formulas (Guillard 1973). Frost's equations (Frost 1972) were used to calculate average cell concentrations (C), clearance (F), and ingestion (I) rates for these same periods. The average concentration of grazers (Favella or Balanion) was calculated assuming exponential growth (Heinbokel 1978).

Experiment 2: effects of initial Heterocapsa triquetra and Favella sp. densities. A 2-way matrix design was used in this experiment to test for the effects of initial densities of Heterocapsa triquetra and Favella sp. and for effects due to the interaction of these 2 factors on $H$. triquetra and Balanion sp. populations after $48 \mathrm{~h}$ incubation. Initial Balanion density was 0.5 cells $\mathrm{ml}^{-1}$. Initial $H$. triquetra densities were 100,500 , and 1000 cells $\mathrm{ml}^{-1}$. Initial Favella densities were 0, 1, and 2.5 cells $\mathrm{ml}^{-1}$. Six $250 \mathrm{ml}$ capacity polycarbonate flasks containing $100 \mathrm{ml}$ of medium were used for each treatment. After inoculation, the contents of 3 flasks from each treatment were fixed with acid Lugol's solution. The remaining 3 flasks in each treatment were incubated at $15^{\circ} \mathrm{C}$ in the dark for $48 \mathrm{~h}$ and then the contents fixed. The cells in $50 \mathrm{ml}$ volumes were counted using the inverted-microscope technique. A logarithmic transformation was done on the counts to correct for multiplicative effects (Sokal \& Rohlf 1981). When the counts included zeros, the data were coded by adding 1 to each variate before the transformation. Two-way analysis of variance (2-way ANOVA) (Sokal \& Rohlf 1981) was used to test for the effects of initial algal and Favella densities and of interaction between the 2 factors on Balanion. By the end of the experiment, $H$. triquetra had disappeared from 7 of the treatments, therefore a t-test for unequal variances (Sokal \& Rohlf 1981) rather than analysis of variance were used with these data.

Experiment 3: gross production efficiencies. The gross production efficiencies (GPE) (production/ingestion; equivalent to gross growth efficiency, ecological efficiency or yield as used by some authors) of Favella sp. and Balanion sp., when feeding on Heterocapsa triquetra were compared in this experiment. It was not possible to determine the production efficiency for Favella when feeding on only Balanion because Favella does not survive on this diet.

Triplicate $250 \mathrm{ml}$ capacity polycarbonate flasks containing $200 \mathrm{ml}$ of medium were used for each treatment. To determine if efficiencies varied with algal food concentrations, 3 initial Heterocapsa triquetra densities were used: 500, 1000, and 3000 cell ml-1. Triplicate control flasks at each algal density were not inoculated with ciliates. Experimental flasks were inoculated with either Favella sp., 1 cell $\mathrm{ml}^{-1}$, or with Balanion sp., 2 cells $\mathrm{ml}^{-1}$. Flasks were incubated at $15^{\circ} \mathrm{C}$ in the dark. Volumes of $100 \mathrm{ml}$ were removed from each flask after 24 and $48 \mathrm{~h}$ incubation. At both sampling times, 10 to $40 \mathrm{ml}$ unfixed samples were electronically sized using a Model TA II Coulter counter with a population accessory and a $400 \mu \mathrm{m}$ aperture tube. The aperture tube was calibrated with $21.84 \mu \mathrm{m}$ polystyrene microspheres. Channel splitting was used to improve particle-size resolution. The sizes of Balanion and Favella were also checked using an ocular micrometer. Sixty $\mathrm{ml}$ subsamples were preserved with acid Lugol's solution and later counted. In 
the treatments with Balanion, $25 \mathrm{ml}$ settled samples were counted; with Favella, $50 \mathrm{ml}$ samples were counted.

Cell counts for each replicate at each sampling time were converted to carbon (C) using the formula:

$$
\mathrm{C}=\mathrm{aV}
$$

where $C=p g C \mathrm{ml}^{-1} ; a=$ the conversion factor for volume to carbon (pg $C \mu \mathrm{m}^{-3}$ ); $V=$ average cell volume $\left(\mu \mathrm{m}^{3}\right)$. Conversion factors were determined from triplicate CHN analysis of the ciliates and volume determinations on cells from the same cultures.

Frost's equations (Frost 1972) were used to calculate the average concentration of Heterocapsa triquetra in pg $\mathrm{C} \mathrm{ml}^{-1}$ and the ingestion rates $(I)$ in pg $\mathrm{C}$ ciliate ${ }^{-1} \mathrm{~h}^{-1}$. The average concentrations $(N)$ of Favella sp. or Balanion sp. were calculated. Ciliate carbon at $24 \mathrm{~h}$ was subtracted from ciliate carbon at $48 \mathrm{~h}$ to get the production $(P)$ for the $24 \mathrm{~h}$ time interval in pg $\mathrm{C}$ $\mathrm{ml}^{-1}$.

Gross production efficiency (GPE), that is production/ingestion, was calculated as:

$$
\mathrm{GPE}=\frac{\mathrm{P}}{24 \times \mathrm{N} \times \mathrm{I}}
$$

Gross production efficiencies were calculated separately for each of the 3 replicates at each food concentration. Because GPE is a proportion, an arcsine transformation was applied (Sokal \& Rohlf 1981) before the data were analysed with a 2-way ANOVA to determine if the GPE's of the 2 ciliates were different and to determine if GPE's were different at different food levels.

Experiment 4: effects of ciliate species composition on grazing impact, numerical growth, and secondary production. This experiment was designed to simultaneously determine if the presence of both ciliates influences grazing impact, the growth of either, and the production of ciliate biomass compared with single ciliate species culture. Additional data were also obtained on the GPE of both ciliates for comparison with Experiment 4. Two initial densities of Heterocapsa triquetra, 500 and 1000 cells $\mathrm{ml}^{-1}$, were used so that the interactions of the 2 ciliates at different algal food levels could be compared. The 4 initial ciliate densities at each algal food level were: (1) control (no ciliates); (2) 1 Favella ml-1; (3) 0.5 Balanion $\mathrm{ml}^{-1}$; (4) 1 Favella and 0.5 Balanion $\mathrm{ml}^{-1}$. Triplicate cultures were incubated at $15^{\circ} \mathrm{C}$ for $46 \mathrm{~h}$. Experimental protocols for determining cell numbers and for measuring production were the same as in previous experiments. A 2-way ANOVA was used to test for the effects of algal density and initial ciliate densities.

\section{EXPERIMENTAL RESULTS}

\section{Experiment 1: growth curves}

With Heterocapsa triquetra present but no Favella sp. the Balanion sp. populations reached $350 \mathrm{ml}^{-1}$ on Day 4 and then rapidly declined (Fig. 1). With Favella present, Balanion reached a lower maximum density, $22 \mathrm{ml}^{-1}$, on Day 3, and declined by Day 5. Favella in the treatment with Balanion contained the remains of Balanion in their food vacoules. Favella's growth was similar whether Balanion was present or absent (Fig. 1) except on Day 8 when the Favella without Balanion appeared to be declining more slowly than the Favella which had been with Balanion.

Algal concentrations were similar in the grazed treatment groups until Day 3 when the cultures with Favella sp. as the only grazer had the highest and the cultures with only Balanion sp. had the lowest Heterocapsa triquetra concentrations (Fig. 2). The cultures with both ciliates had intermediate $H$. triquetra densities. This trend persisted until the algae were almost completely removed by grazing. The reduced Balanion densities in the treatments with Favella cannot be ascribed to competition for food because more food was present on Days 3 and 4 in the treatments with Favella than without Favella.

From Fig. 1 \& 2, the periods during which exponential growth occurred were identified; for these periods growth rates were estimated (Table 1). In Treatment 1 ( $H$. triquetra alone) the generation time for $H$. triquetra

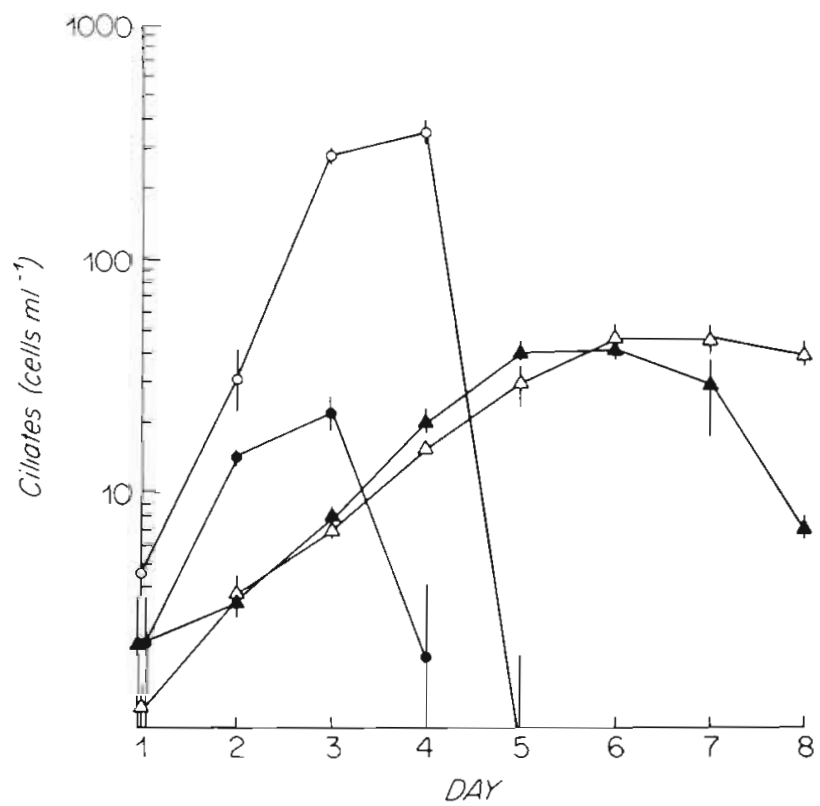

Fig. 1. Average densities of Balanion sp. and Favella sp.; Experiment 1. Ranges indicated by vertical bars. O Balanion alone; Balanion with Favella; $\triangle$ Favella alone; $\Delta$ Favella with Balanion 


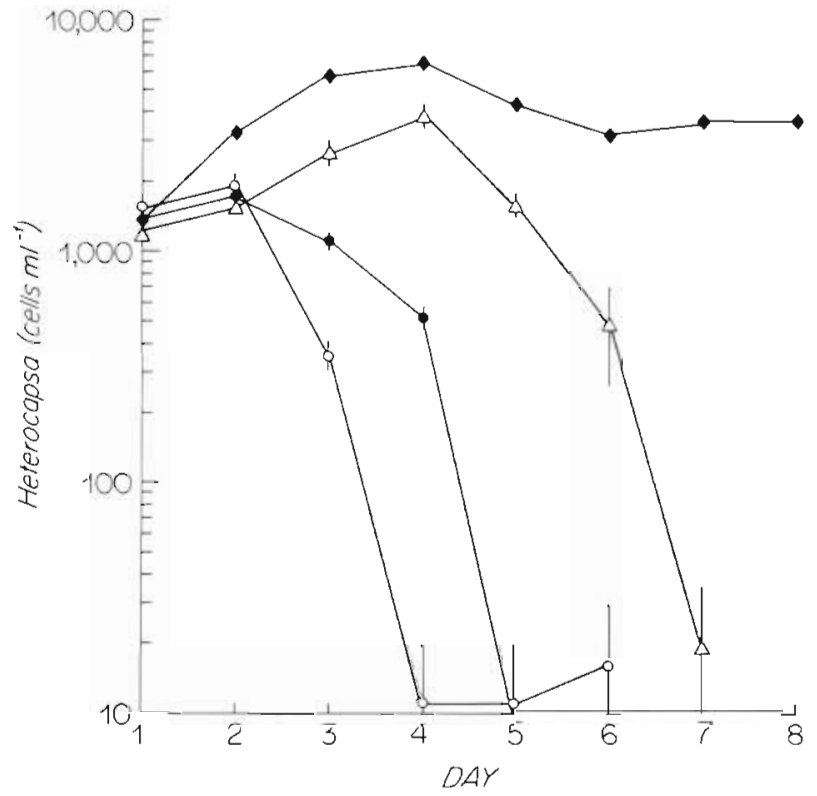

Fig. 2. Average densities of Heterocapsa triquetra; Experiment 1. Ranges indicated by vertical bars. control; $O$ with Balanion sp.; $\triangle$ with Favella sp.; with Balanion and Favella

over Days 1 to 3 was about $23 \mathrm{~h}$. In Treatment 2 ( $H$. triquetra plus Balanion) the generation time for Balanion for Days 1 to 3 was about $8 \mathrm{~h}$. The generation time for Favella was estimated for Days 1 to 4 ; in Treatment 3 (H. triquetra plus Favella) it was about $20 \mathrm{~h}$ and in Treatment 4 (H. triquetra, Balanion, and Favella) it was about $23 \mathrm{~h}$.

For the periods in which exponential growth occurred, feeding rates were also estimated (Table 1). It was assumed that the growth of Heterocapsa triquetra was similar in all flasks for the first $3 \mathrm{~d}$ of the experiment. The volume swept clear $(\mathrm{F})$ by Balanion is about $1 \mu \mathrm{l}$ ciliate ${ }^{-t} h^{-1}$; the number of algae ingested appears to be proportional to the algal density. This is consistent with earlier results (Stoecker unpubl.). Favella con-
Table 1. Feeding rates of Favella sp. and Balanionsp. (Experiment 1). $\langle\mathrm{C}\rangle$ : av. cell concentration (cells $\mathrm{ml}^{-1}$ ) $\mathrm{F}$ : = volume swept clear $\left(\mu l\right.$ ciliate $\left.^{-1} h^{-1}\right)$; I: ingestion rate (cells ciliate ${ }^{-1}$ $h^{-1}$ )

\begin{tabular}{|ccrrr|}
\hline & $\begin{array}{c}\text { Repli- } \\
\text { cate }\end{array}$ & $\langle\mathrm{C}\rangle$ & $\mathrm{F}$ & $\mathrm{I}$ \\
\hline Balanion on Heterocapsa & & & & \\
Day 1-2 & 1 & 1893 & 1.2 & 2.3 \\
& 2 & 1299 & 1.2 & 1.6 \\
Day 2-3 & 1 & 1012 & 0.8 & 0.8 \\
& 2 & 786 & 1.0 & 0.8 \\
Favella on Heterocapsa & & & & \\
Day 1-2 & 1 & 1460 & 9.9 & 14.5 \\
& 2 & 1341 & 11.4 & 15.3 \\
Day 2-3 & 1 & 2032 & 1.4 & 2.8 \\
& 2 & 2052 & 1.0 & 2.0 \\
Favella on Balanion & & & & \\
Day 2-3 & 1 & 16.6 & 12.2 & 0.2 \\
& 2 & 19.4 & 15.0 & 0.3 \\
\hline
\end{tabular}

sumed 14.9 dinoflagellates ciliate ${ }^{-1} \mathrm{~h}^{-1}$ on Days 1 and 2

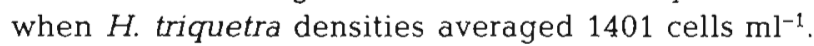
On Days 1 and 2 Favella only consumed 2.4 dinoflagellates ciliate $\mathrm{C}^{-1} \mathrm{~h}^{-1}$; during this period $H$. triquetra densities averages 2042 cells $\mathrm{ml}^{-1}$ (Table 1). These values are within the range previously reported for Favella grazing on dinoflagellates (Stoecker \& Guillard 1982) and are consistent with inhibition of feeding at $H$. triquetra densities over 1000 to $1500 \mathrm{ml}^{-1}$ (Stoecker unpubl.). The predation rate of Favella on Balanion (at an average Balanion concentration of 18 $\mathrm{ml}^{-1}$ ) was 0.25 Balanion Favella $\mathrm{a}^{-1} \mathrm{~h}^{-1}$. The volume swept clear by Favella, $14 \mu \mathrm{l}$ ciliate ${ }^{-1} \mathrm{~h}^{-1}$, with Balanion as prey was within the range, 1 to $25 \mu$ ciliate ${ }^{-1} \mathrm{~h}^{-1}$, reported with dinoflagellates as prey (Stoecker \& Guillard 1982).

Table 2. Effect of initial Heterocapsa $(\mathrm{H})$ and Favella $(\mathrm{F})$ conc. (cells $\mathrm{ml}^{-1}$ ) on Heterocapsa and Balanion conc. after 48 h. Experiment 2; initial Balanion conc. 0.5 cells $\mathrm{ml}^{-1}$

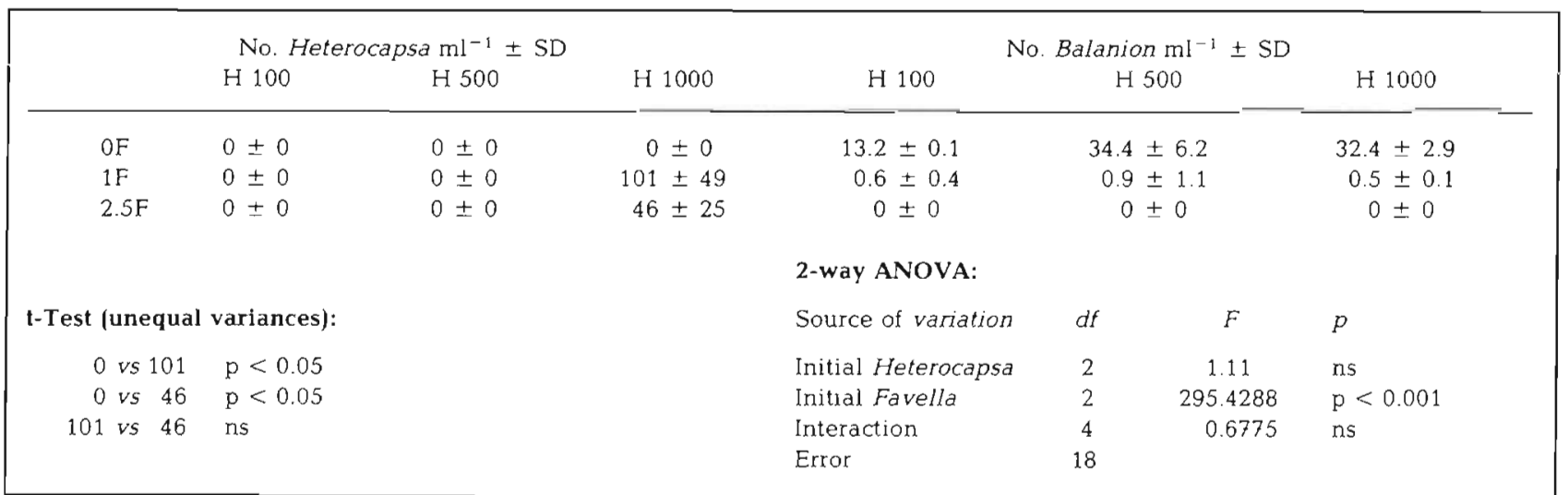




\section{Experiment 2: effects of initial Heterocapsa triquetra and Favella sp. densities}

Favella sp. had a significant inhibitory effect on the density of Balanion sp. by $48 \mathrm{~h}$ (Table 2). In this experiment, the effects of initial Heterocapsa triquetra density were not significant (Table 2). At the end of the incubation, there were significantly more $H$. triquetra when Favella was present than when it was absent in the highest food density treatments; at the lower food densities all the algae had been grazed.

\section{Experiment 3: gross production efficiencies}

The conversion factor, a (see Eq. [1]), for volume to carbon is $0.136 \mathrm{pg} \mathrm{C} \mu \mathrm{m}^{-3}$ for Heterocapsa triquetra and 0.10 for Favella sp. and Balanion sp. Favella and Balanion had a similar response, in terms of gross production efficiency (GPE), to variations in algal food density (Table 3 ). At initial $H$. triquetra densities of 500 and 1000 cells ml-1 (average food biomass 20 to $100 \mu \mathrm{g}$ carbon $\mathrm{l}^{-1}$ ), both ciliates had a GPE above $50 \%$. At an initial $H$. triquetra density of 3000 cells $\mathrm{ml}^{-1}$ (average food biomass 344 to $393 \mu$ g carbon ${ }^{-1}$ ), both Favella and Balanion had a lower GPE, 21 and $25 \%$ respectively; however, these were not statistically different from each other $(p>0.05)$. At the highest food density, some of the fecal particles produced by the ciliates contained undigested $H$. triquetra cells.

Table 3. Mean ( \pm SD) Gross Production Efficiencies (GPE) of Favella sp. and Balanion sp. at $15^{\circ} \mathrm{C}$. Food: Heterocapsa triquetra

\begin{tabular}{|c|c|c|c|}
\hline \multicolumn{4}{|c|}{ Food availability } \\
\hline \multirow{2}{*}{$\begin{array}{c}\text { Initial } \\
\text { Heterocapsa } \\
\text { (cells } \mathrm{ml}^{-1} \text { ) }\end{array}$} & \multicolumn{2}{|c|}{$\begin{array}{c}\text { Av. } \\
\text { Heterocapsa }\end{array}$} & \multirow{2}{*}{$\begin{array}{l}\text { GPE } \\
(\%)\end{array}$} \\
\hline & (cells ml-1) & $\left(\mu g \mathrm{Cl}^{-1}\right)$ & \\
\hline \multicolumn{4}{|c|}{ Favella } \\
\hline $500^{\mathrm{a}}$ & 131 & 26 & $64 \pm 4$ \\
\hline $500^{\mathrm{ib}}$ & 135 & 21 & $51 \pm 4$ \\
\hline $1000^{\mathrm{a}}$ & 422 & 82 & $69 \pm 5$ \\
\hline $1000^{\mathrm{b}}$ & 499 & 76 & $54 \pm 11$ \\
\hline $3000^{\mathrm{a}}$ & 1765 & 344 & $21 \pm 5$ \\
\hline \multicolumn{4}{|c|}{ Balanion } \\
\hline $500^{\mathrm{a}}$ & 218 & 43 & $53 \pm 4$ \\
\hline $500^{\mathrm{b}}$ & 278 & 42 & $50 \pm 4$ \\
\hline $1000^{\mathrm{a}}$ & 462 & 90 & $54 \pm 6$ \\
\hline $1000^{b}$ & 648 & 98 & $61 \pm 12$ \\
\hline $3000^{a}$ & 2017 & 393 & $25 \pm 8$ \\
\hline \multicolumn{4}{|c|}{${ }^{a}$ Experiment 3} \\
\hline \multicolumn{4}{|c|}{${ }^{\mathrm{b}}$ Experiment 4} \\
\hline
\end{tabular}

Experiment 4: effects of ciliate species composition on grazing impact, numerical growth, and secondary production

At the end of the $46 \mathrm{~h}$ incubation, grazing had reduced the Heterocapsa triquetra density in all treatments with ciliates (Fig. 3). However, the effects of Favella sp. and Balanion sp. grazing on $H$. triquetra

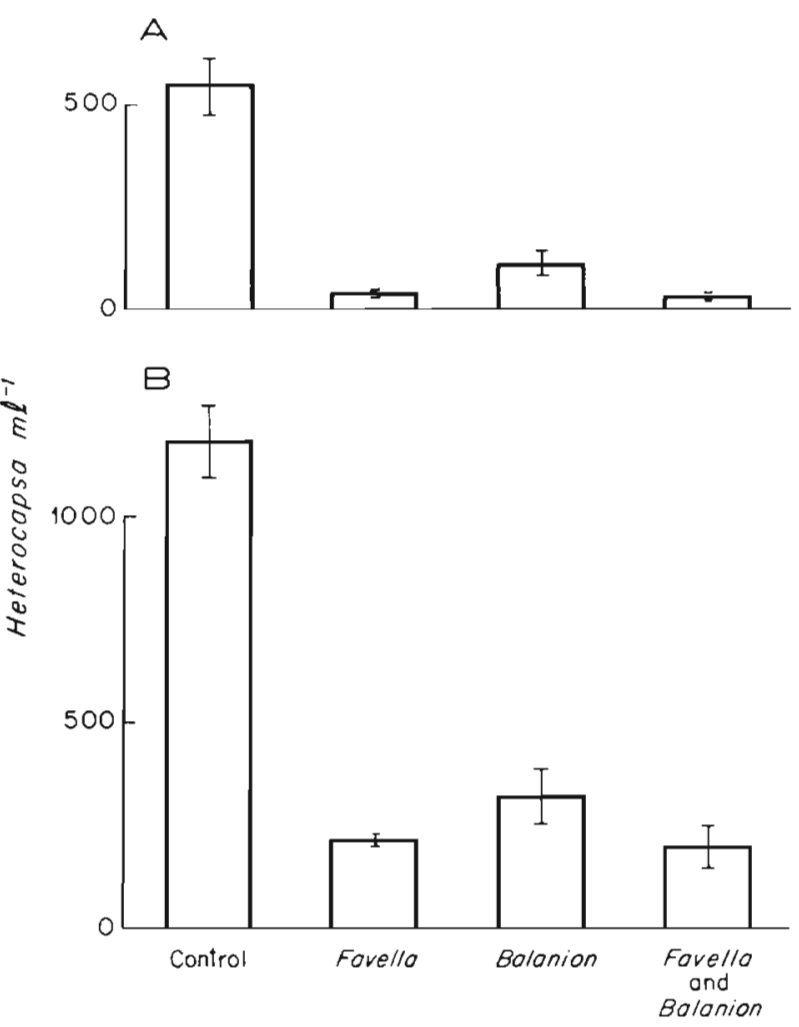

Fig. 3. Heterocapsa triquetra density (mean \pm SD) 46 h after inoculation with Favella sp., Balanion sp., and both. Initial densities were 1.0 Favella, 0.5 Balanion, and 500 (A) or 1000 (B) H. triquetra $\mathrm{ml}^{-1}$; Experiment 4

$$
\text { 2-way ANOVAS: }
$$

A

\begin{tabular}{|lrrr|}
\hline Source of variation & $\mathrm{df}$ & $\mathrm{F}$ & $\mathrm{p}$ \\
\hline Initial Balanion & 1 & 70.75 & $<0.001$ \\
Initial Favella & 1 & 187.96 & $<0.001$ \\
Interaction & 1 & 50.27 & $<0.001$ \\
Error & 8 & & \\
\hline
\end{tabular}

$\mathrm{B}$

\begin{tabular}{llrl|}
\cline { 2 - 4 } Source of variation & $\mathrm{df}$ & $\mathrm{F}$ & $\mathrm{p}$ \\
\hline Initial Balanion & 1 & 69.42 & $<0.001$ \\
Initial Favella & 1 & 132.71 & $<0.001$ \\
Interaction & 1 & 60.36 & $<0.001$ \\
Error & 8 & & \\
\hline
\end{tabular}


were not additive; $H$. triquetra numbers were greater than expected. This interaction was significant at both algal densities (Fig. 3). The effect was not as striking as in Experiment 1, where adding Favella to $H$. triquetra and Balanion appeared to have increased the number of $H$. triquetra (Fig. 2). As in Experiment 2, Balanion concentrations were lower in the presence of Favella but the impact of Favella on Balanion was greater at the higher algal density (Fig. 4). Balanion did not have a significant effect on the number of Favella (Fig. 5).

In single ciliate species culture, secondary production was greater for Balanion sp. than for Favella sp. (Fig. 6). Secondary production for the 24 to $46 \mathrm{~h}$ interval was significantly lower when both ciliates were present than when either was grown separately. The negative effect of the presence of both ciliates on production was more dramatic at the lower algal density (Fig. 6). For Favella or Balanion grown singly, the GPE was $50 \%$ or greater (Table 3 ).

\section{MODEL}

We investigated the type of food web structure exemplified by interactions among Favella sp., Balan-

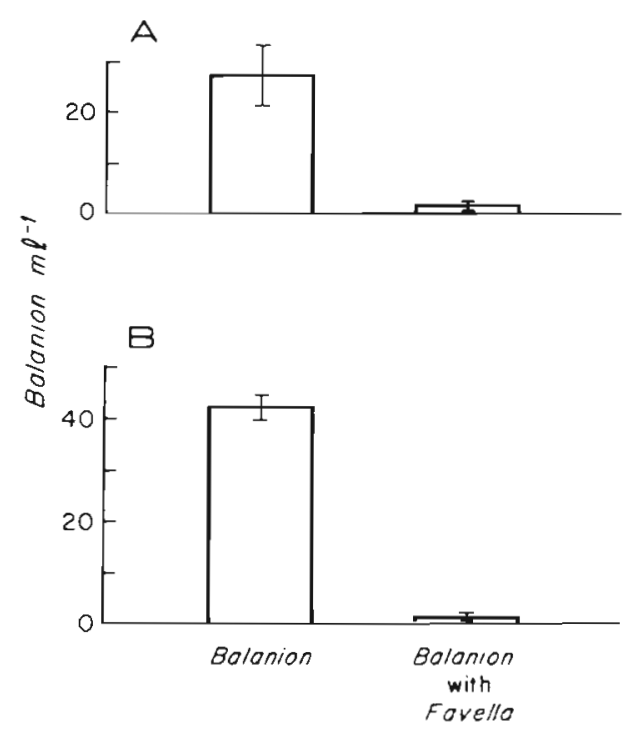

Fig. 4. Balanion sp. density (mean \pm SD) 46 h after inoculation with Balanion $\left(0.5 \mathrm{ml}^{-1}\right)$ in the presence and absence of Favella sp. at 2 initial Heterocapsa triquetra densities, 500 (A) and 1000 (B) $\mathrm{ml}^{-1}$; Experiment 4

2-way ANOVAS:

\begin{tabular}{lrrll|}
\hline Source of variation & df & \multicolumn{1}{c|}{ F } & \multicolumn{1}{c|}{ p } \\
\hline Initial Heterocapsa & 1 & 8.75 & $<0.05$ \\
Favella & 1 & 226.11 & $<0.001$ \\
Interaction & 1 & 11.89 & $<0.05$ \\
Error & 8 & & \\
\hline
\end{tabular}

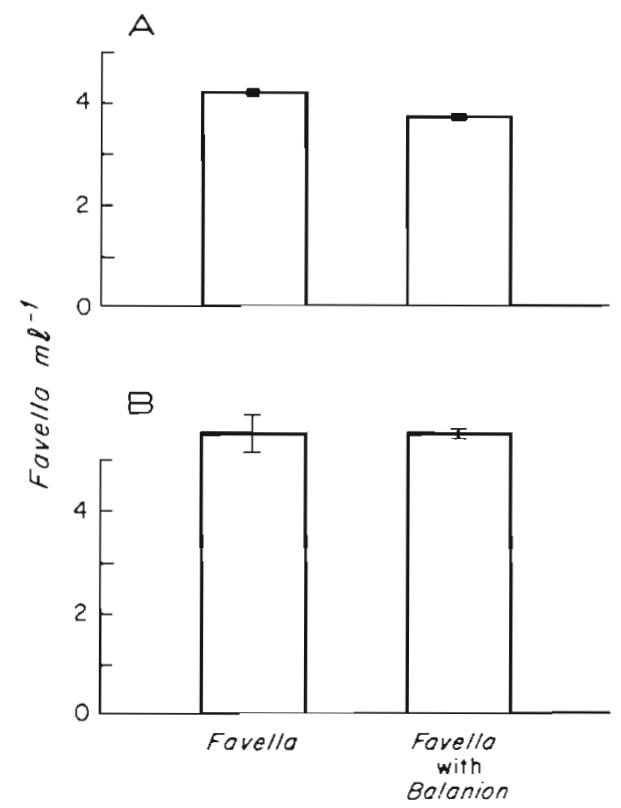

Fig. 5. Favella sp. density (mean $\pm \mathrm{SD}$ ) $46 \mathrm{~h}$ after inoculation with Favella $\left(1.0 \mathrm{ml}^{-1}\right)$ in the presence and absence of Balanion sp. $\left(0.5 \mathrm{ml}^{-1}\right)$ at 2 initial Heterocapsa triquetra densities, 500 (A) and 1000 (B) $\mathrm{ml}^{-1}$; Experiment 4

2-way ANOVAS (ns: not significant):

\begin{tabular}{llrc|}
\hline Source of variation & df & F & p \\
\hline Initial Heterocapsa & 1 & 118.00 & $<0.001$ \\
Balanion & 1 & 2.13 & ns \\
Interaction & 1 & 2.27 & $n s$ \\
Error & 8 & & \\
\hline
\end{tabular}

ion sp., and Heterocapsa triquetra using a theoretical model. We did not intend (indeed, we do not know enough) to construct a simulation model of the system. We omitted important features of in situ population dynamics such as formation and hatching of cysts, satiation of predators, and carnivore population dynamics. Our intention was to seek effects similar to those we observed in laboratory experiments in a setting simple enough to be analysed.

We considered the following model of populations of Heterocapsa triquetra (H), Balanionsp. (B) and Favella sp. $(F)$ :

$$
\begin{aligned}
& \frac{d H}{d t}=r H-s H^{2}-\alpha H B-\gamma H F \\
& \frac{d B}{d t}=\varepsilon_{\alpha} \alpha H B-\beta B F-\psi B \\
& \frac{d F}{d t}=\varepsilon_{\beta} \beta B F+\varepsilon_{\gamma} \gamma H F-\varphi F
\end{aligned}
$$

Growth, grazing and mortality are described by familiar Lotka-Volterra terms: $r=$ per capita growth rate of $H$. triquetra at low densities; $r / s=$ carrying capacity 

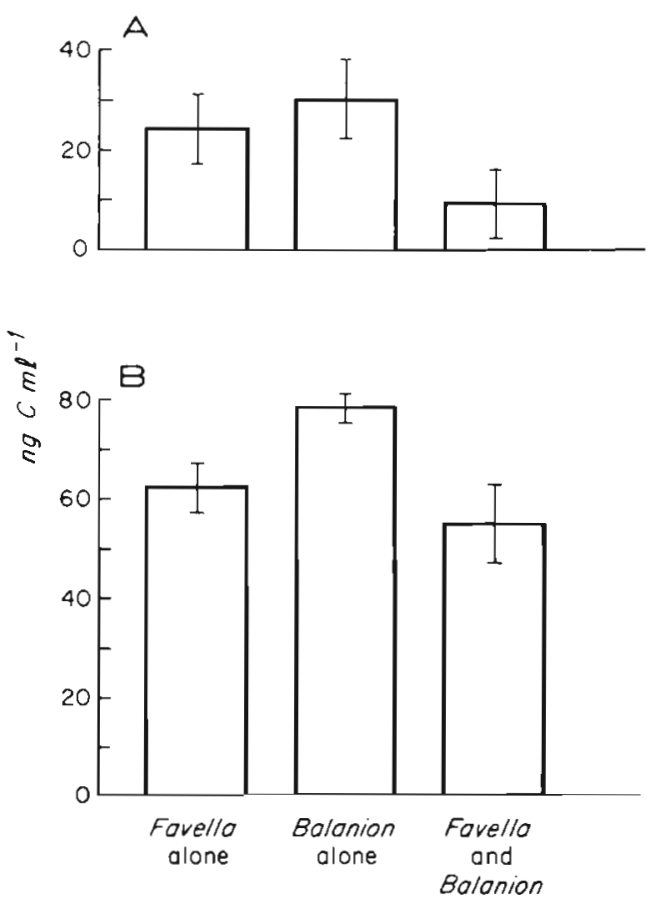

Fig. 6. Production of ciliate biomass (mean \pm SD) over $22 \mathrm{~h}$ incubation when Favella sp. and Balanion sp. were grown separately and together at low (A) and high (B) Heterocapsa triquetra densities; Experiment 4

2-way ANOVAS (ns: not significant):

\begin{tabular}{|lrrc|}
\hline \multicolumn{1}{|c}{ Source of variation } & df & \multicolumn{1}{c|}{$\mathrm{F}$} & $\mathrm{p}$ \\
\hline Initial Heterocapsa density & 1 & 114.9 & $<0.001$ \\
Ciliate species composition & 2 & 14.7 & $<0.002$ \\
Interaction & 2 & 0.1 & ns \\
Error & 12 & & \\
\hline
\end{tabular}

for $H$. triquetra in the absence of specific predators. The total rate of grazing of Balanion on $H$. triquetra is $\alpha H B$, proportional to the product of their concentrations. Grazing of Favella on Balanion is $\beta B F_{;}$of Favella on Heterocapsa, $\gamma H F$. The terms $\psi B$ and $\varphi F$ represent constant per capita mortality rates of $B$ and $F$. The factors $\varepsilon_{\alpha}, \varepsilon_{\beta}$, and $\varepsilon_{\gamma}$ represent gross production efficiencies: the fraction of ingested grazer material converted to growth. Because of the triangular nature of the model, it is possible to compare efficiencies of different food pathways between 2 species, something which would make no sense in a food chain model. The relative values of these efficiencies will have an important effect on ecosystem structure.

The experiments reported here did not approach a steady state; and neither does the estuary which inspired them. In the estuary, there is instead a transient outburst, initiated by the germination of dinoflagellate and perhaps protozoan cysts, which lasts a few weeks, and which is terminated largely by the formation of new dinoflagellate cysts (Anderson et al. 1983, Stoecker et al. 1983). Nevertheless, we investigated this model by examining steady-state solutions. It is at least plausible that changes in the steady state would entail similar changes in the annual cycle. We can draw conclusions that apply to other systems which may be governed for a longer time by differential equation models, and the analysis of steady state can be carried further than the analysis of transient behavior.

It is possible to choose parameters so that the system has a positive, stable equilibrium. Details will be furnished by G.T.E. on request.

The question: How does omnivory influence the system? can now be expressed more precisely (bearing in mind the difference between precision and accuracy) as: How do changes in the coefficients of Eq. (3) to (5) alter the steady-state concentrations?

If Favella sp. increases its grazing on Heterocapsa triquetra ( $y$ increases), the direct effect is to reduce the $H$. triquetra concentration; but indirect effects, brought about by increased Favella populations increasing the grazing pressure on Balanion sp., cannot be predicted on the basis of verbal descriptions alone. Within the model, if we assume $\psi=0$ (predation by Favella is the only source of Balanion mortality) then the long-term effect of changing $\gamma$ depends on the sign of $\left(\varepsilon_{\alpha} \varepsilon_{\beta}-\varepsilon_{\gamma}\right)$. If this term is positive (if it is more efficient for Favella to feed on $H$. triquetra in the form of Balanion than directly; a human analogy is eating grass in the form of cattle) then increasing $\gamma$ decreases $\mathrm{H}^{*}$, the steady state value of $H$. If, however, $\left(\varepsilon_{\alpha} \varepsilon_{\beta}-\varepsilon_{\gamma}\right)$ is negative, so that it is more efficient for Favella to feed on H. triquetra directly (a human analogy is eating fish directly rather than as chickens that have been fed fish-meal), then increasing $\gamma$ produces an increase in $\mathrm{H}^{*}$. In this instance, it might be to the long-term detriment of a population to develop defences against one of its predators.

Next, suppose that Favella sp. were to alter its pattern of grazing. We suppose that $\beta+\gamma$ represents the total effort that Favella puts into feeding, and consider the consequences of a reduction of $\gamma$ together with an increase of $\beta$ so that $\beta+\gamma$ remains constant. Rather than looking at the abstract equations with effects going in all directions, consider the following examples:

Example $1(\gamma=3.2, \beta=1.6)$

$$
\begin{aligned}
& \frac{\mathrm{dH}}{\mathrm{dt}}=\mathrm{H}(1-\mathrm{H}-1.6 \mathrm{~B}-3.2 \mathrm{~F}) \\
& \frac{\mathrm{dB}}{\mathrm{dt}}=\mathrm{B}(\mathrm{H}-1.6 \mathrm{~F}-0.5) \\
& \frac{\mathrm{dF}}{\mathrm{dt}}=\mathrm{F}(0.8 \mathrm{~B}+0.95 \mathrm{H}-0.7)
\end{aligned}
$$


Example $2(\gamma=4.8, \beta=0)$

$$
\begin{aligned}
& \frac{\mathrm{dH}}{\mathrm{dt}}=\mathrm{H}(1-\mathrm{H}-1.6 \mathrm{~B}-4.8 \mathrm{~F}) \\
& \frac{\mathrm{dB}}{\mathrm{dt}}=\mathrm{B}(\mathrm{H}-0.5) \\
& \frac{\mathrm{dF}}{\mathrm{dt}}=\mathrm{F}(0.95[1.5] \mathrm{H}-0.7)
\end{aligned}
$$

In both examples, $\beta+\gamma=4.8$, and $\varepsilon_{\alpha}=0.625, \varepsilon_{\beta}=0.5$, $\varepsilon_{y}=0.2969$, so that $\varepsilon_{a} \varepsilon_{\beta}-\varepsilon_{\gamma}>0$. In Example 1, the steady state is $\mathrm{H}^{*}=0.55, \mathrm{~B}^{*}=0.23, \mathrm{~F}^{*}=0.03$. In Example 2, where Favella does not prey on Balanion, there is no steady state with all 3 species present, F outcompetes $\mathrm{B}$, and the stable steady state is $\mathrm{H}^{*}=$ $0.49, \mathrm{~B}^{\circ}=0, \mathrm{~F}^{*}=0.11$. Balanion can survive in the system only if Favella grazes partly on Balanion (the more efficient but less abundant path) instead of wholly on Heterocapsa triquetra.

\section{CONCLUSION}

Favella sp. and Balanion sp. have different patterns of grazing pressure on dinoflagellates. For comparable initial populations, the higher ingestion rate of Favella gives it a greater initial impact, but the shorter generation time of Balanion gives it a potentially greater long-term impact.

The gross production efficiencies (GPE) were within the range reported for marine ciliates by Heinbokel (1978), Rassoulzadegan (1982) and Verity (1984). The decrease in GPE of Favella sp. and Balanion sp. grown at high food concentrations (Table 3 ) is consistent with Heinbokel's (1978) and Verity's (1984) observations of declines in GPE at high food densities.

The production experiment (Fig, 6) demonstrated that the horizontal link created by Favella sp. predation on Balanion sp. could decrease secondary production. However, the magnitude of this effect on yield is determined by the relative importance of the Heterocapsa-Favella and Heterocapsa-BalanionFavella pathways. The impact of Favella on Balanion was influenced by both Heterocapsa and Balanion densities, thus the relative importance of the horizontal links must vary.

Our experiments all demonstrated the same qualitative effects. The differences in magnitude are not surprising, because the experiments were done with batch cultures and thus all 3 organisms varied in physiological state. As would be expected, both growth and feeding rates of the ciliates changed during incubation (Table 1). In the estuary also, growth, and probably feeding rate, varies from day to day (Stoecker et al. 1983). However, an important difference between our experiments and nature is that in nature the dino- flagellates, at least some of the time, must be growing rapidly, whereas in our experiments algal growth was limited by light and nutrients.

In our model of the Heterocapsa-Balanion-Favella trophic triangle, the relative gross production efficiencies of the Heterocapsa-Favella and the HeterocapsaBalanion-Favella pathways have an important effect on ecosystem structure. Our experimental results are consistent with the alternative in our model in which it is less efficient for Favella sp. to eat Heterocapsa triquetra in the form of Balanion $\left(\varepsilon_{\alpha} \varepsilon_{\beta}-\varepsilon_{\gamma}\right.$ is negative). At $15{ }^{\circ} \mathrm{C}$ and moderate $H$. triquetra densities (Table 3 ), Favella sp. and Balanion sp. have similar gross growth efficiencies $\left(\varepsilon_{\beta} \simeq \varepsilon_{\gamma}\right)$. Because $\varepsilon_{\alpha}$ must be $<1, \varepsilon_{\alpha} \varepsilon_{\beta}$ must be less than $\varepsilon_{\gamma}$. This conclusion is supported by Experiment 4 , in which production of ciliate biomass was less with both ciliates present than with only one (Fig. 6). The effect on total ciliate production was greater at lower $H$. triquetra densities than at higher $H$. triquetra densities probably because the Balanion-Favella link was relatively more important at the lower algal density.

In a triangular food web, where trophic position is ambiguous, we have 2 examples where increasing the rate of predation on a species can increase its stable, steady-state concentration. As with all such models, restriction to 3 species entails ad hoc allowances for interactions with the rest of the estuarine community, with the attendant danger that our conclusions will depend as much on these allowances as on the features in which we are interested. This is a problem, not of modelling, but of trying to understand an isolated part of a large system; the model only makes the problem explicit.

Under our experimental conditions, the system does not reach a steady state and both alga and the ciliate populations ultimately decline. In the field this also is true, but perhaps for different reasons. During spring and fall dinoflagellate blooms, both physical-chemical conditions and biotic factors change. Omnivory by Favella sp. may not be capable of making these systems stable but may have important influences on the length of blooms. Reduced grazing pressure on Feterocapsa triquetra because of Favella predation on Balanion sp. may allow greater opportunity for $H$. triquetra to form cysts which can seed new blooms (Anderson et al. 1983).

Our results suggest that triangular trophic structure may have important consequences for ecosystem structure. This type of trophic structure may be common among the microplankton because many heterotrophic microplankters are about the same size as their prey and thus competitors may often also be predators and prey. These complex trophic relationships are probably important in regulating grazing pressure by mi- 
crozooplankton and microzooplankton secondary production.

Acknowledgements. A. Michaels provided technical assistance. E. Small and D. W. Coats identified Balanion sp.; G. Capriulo, D. Caron, L. H. Davis, D. Egloff and M. Levandowsky criticized early drafts of the manuscript. The work was supported by the Dept. of Commerce, NOAA grant NA81RAD0014 and NSF grant OCE-8200030.

\section{LITERATURE CITED}

Anderson, D. A., Chisholm, S. W., Watras, C. J. (1983). The importance of life cycle events in the population dynamics of Gonyaulax tamarensis. Mar. Biol. 76: 179-189

Blackbourn, D. J. (1974). The feeding biology of tintinnid protozoa and some other inshore microzooplankton. Ph. D. thesis, Univ. of British Columbia, Vancouver

Capriulo, G. M. (1982). Feeding of field collected tintinnid micro-zooplankton on natural food. Mar. Biol. 71: 73-86

Capriulo, G. M., Carpenter, E. J. (1980). Grazing by 35 to 202 $\mu \mathrm{m}$ micro-zooplankton in Long Island Sound. Mar. Biol. 56: $319-326$

Capriulo, G. M., Carpenter, E. J. (1983). Abundance, species composition and feeding impact of tintinnid micro-zooplankton in central Long Island Sound. Mar. Ecol. Prog. Ser. 10: 277-288

Frost, B. W. (1972). Effects of size and concentration of food particles on the feeding behavior of the marine planktonic copepod Calanus pacificus. Limnol. Oceanogr. 6: 805-815

Guillard, R. R. L. (1973). Division rates. In: Stein, J. R. (ed.) Handbook of phycological methods - culture methods and growth measurements. Cambridge Univ. Press, Cambridge, p. 289-311

Guillard, R. R. L. (1975). Culture of phytoplankton for feeding marine invertebrates. In: Smith, W. L., Chanley, M. H. (ed.) Culture of marine invertebrate animals. Plenum Publishing Corp. New York, p. 29-60

Heinbokel, J. (1978). Studies on the functional role of tintinnids in the southern California Bight. II. Grazing rates of field populations. Mar. Biol. 47: 191-197

Heinbokel. J. F., Beers, J. R. (1979). Studies on the functional role of tintinnids in the southern California Bight. III. Grazing impact of natural assemblages. Mar. Biol. 52: $23-32$
Isaacs, J. D. (1972). Unstructured marine food webs and pollutant analogues. Fish. Bull. U. S. 70: 1053-1059

Isaacs, J. D. (1977). The life of the open sea. Nature, Lond. 267: $778-780$

Landry, M. R. (1981). Switching between herbivory and carnivory by the planktonic marine copepod Calanus pacificus. Mar. Biol. 65: 77-82

Landry, M. R., Hassett, R. P. (1982). Estimating the grazing impact of marine micro-zooplankton. Mar. Biol. 67: $283-288$

Levandowsky, M. (1977). Multispecies cultures and microcosms. In: Kinne, O. (ed.) Marine ecology, Vol. III, Cultivation, Part 3. John Wiley and Sons, Chichester, p. $1399-1458$

Rassoulzadegan, F. (1982). Dependence of grazing rate, gross growth efficiency and food size range on temperature in a pelagic oligotrichous ciliate Lohmanniella spiralis Leeg., fed on naturally occurring particulate matter. Annls. Inst. océanogr., Paris 58: 177-184

Rescigno, A. (1968). The struggle for life: II. Three competitors. Bull. Math. Biophys. 30: 291-298

Rescigno, A., Jones, K. G. (1972). The struggle for life: III. A predator-prey chain. Bull. Math. Biophys. 34: 521-532

Robertson, J. R. (1983). Predation by estuarine zooplankton on tintinnid ciliates. Estuar. coast. Shelf Sci. 16: 27-36

Sokal, R. R., Rohlf, F. J. (1981). Biometry. 2nd Ed. W. H. Freeman and Co., San Francisco

Steele, J. H. (1974). The structure of marine ecosystems. Harvard Univ., Cambridge

Stoecker, D. K., Davis, L. H., Anderson, D. M. (1984). Fine scale spatial correlations between planktonic ciliates and dinoflagellates. J. Plankton Res. 6: 829-842

Stoecker, D., Davis, L. H., Provan, A. (1983). Growth of Favella sp. (Ciliata: Tintinnia) and other microzooplankters in cages incubated in situ and comparison to growth in vivo. Mar. Biol. 75: 293:302

Stoecker, D., Guillard, R. R. L. (1982). Effects of temperature and light on the feeding rate of Favella sp. (ciliated protozoa, suborder Tintinnia). Annls Inst. océanogr, Paris 58(5): 309-318

Stoecker, D., Guillard, R. R. L., Kavee, R. M. (1981). Selective predation by Favella ehrenbergii (Tintinnia) on and among dinoflagellates. Biol. Bull. Mar. biol. Lab., Woods Hole 160: 136-145

Verity, P. G. (1984). The physiology and ecology of tintinnids in Narragansett Bay, Rhode Island. Ph. D. thesis, Univ. of Rhode Island, Kingston, p. 1-475 